\title{
Quantum Humanism as a Framework for Sustainable Workplaces
}

\author{
Carlos Largacha-Martinez, Ph. D. \\ Universidad EAN, Colombie
}

\section{INTRODUCTION}

Just think about the following situation in a workplace. A subordinate is having trouble with his boss. He thinks that he is autocratic, on occasion, abusive in his role-attached power, poorly democratic, and he maintains an uncomfortable organizational climate in his area. He manages a group which is composed by ten employees. After two years of living this situation, he starts looking for a new job. He wants a workplace in which he can be the boss and manage it the opposite way than his bosses have been doing it in the past. He talks with all his friends about his dream of a democratic and humanistic workplace. He has heard that it is possible, but he doesn't have the time to learn more about it. Suddenly, his boss resigns and the general manager offers him the job. The boss just tells him, using his traditional command \& control behavior, "I hope you make the right decision. Once you accept the job, you will have to demonstrate good results during the next quarter term. You are the best in the group, although I think you need a lot of experience to become a real manager. See you".

The new manager doesn't know what to do. However, this may be the opportunity he has been waiting for. A possibility to change everything he dislikes. He accepts the job. After six months of being the new manager, one of his subordinates comes to his office. He looks at him, sits down and tells him "I'm sorry I am leaving today. I didn't let you know before because I was called yesterday to confirm my new position. I think you are a good human being, with high ethical standards. However, you are autocratic, several times, you abuse of your role-attached power, you are poorly democratic and you maintain an uncomfortable organizational climate in this area. Good luck and good bye". The manager was speechless, not because of the action of his subordinate, but because of the fact that he would resign. They were almost the same as he thought a year ago. What happened with him? Has he been transformed himself into another typical, authoritarian, command-and-control "boss"? Why?

Has something similar happened to you? Have you seen or experienced something similar to the story that you just read? As part of the research that I have done and the personal experiences that I have lived, this story is typical. Several times, co-workers have told me that they are bored with their boss. Later, without having that goal in mind, a subordinate of the abovementioned person tells me that the actions done by their boss resembles what the first person told me. Why? Again, why? Is this simply natural? Is this the structure of any capitalistic company? Why do people behave against their supposed moral standards? What is it that workplaces have to convert subordinates into non-ethical bosses? It seems, that the more power you have, the more 'something' pushes you, converts you, presses you to become a non-humanistic leader. This paper will give some answers to what exactly this 'something' is; of what it is made of. By giving explanations to this so-called conundrum, we will also explore the foundations of a humanistic workplace, and what should be done to finally achieve that goal.

Why do people behave against their supposed moral standards? What is it that workplaces have to convert subordinates into non-ethical bosses? It seems, that the more power you have, the more 'something' pushes you, converts you, presses you to become a nonhumanistic leader. 


\section{LINKING QUANTUM HUMANISM WITH MANAGEMENT}

\section{Those who are able to listen quietly to the Other as another being are the ones that could constitute a community and not a merely totalized society.}

The foundational approach that is presented here is Quantum Humanism, or Holistic Alterity, which is countercultural to the rational-logical pillars of mainstream Western thought. Quantum relates to the subatomic world, which has a holistic constitution. Alterity relates to an ethical position in how to behave towards another human being. Here, Alterity will be dealt with as a humanistic philosophy. That explains why Humanism is akin to Alterity and Quantum is akin to Holistic. It is an alterity - or the apprehension of the Other as a truly Other - that is consistent with the philosophy developed by scholars like Heidegger, Levinas, Apel, Gadamer and Zea, as well as with radical diversity like Kymlicka and Fals-Borda.

Although throughout paper several scholars will be consulted to describe the social philosophical foundations of Quantum Humanism, the Philosophy of Liberation from Latin American philosopher Enrique Dussel is the foundation of this endeavor. In order to connect the humanistic ideas from Dussel with the quantum ideas of scholars, two social psychologists-who I consider to be holistic thinkers - are documented. First, Carl Jung's ideas of collective consciousness and inflation; and second, Abraham Maslow's ideas of self-actualization and B-humans. Some quantum scholars are cited like Zohar, Capra, Penrose, Laudisa \& Rovelli. As a framework, Enrique Dussel argues "those who are able to listen quietly to the Other as another being are the ones that could constitute a community and not a merely totalized society". Pierre Teilhard de Chardin (1999: 43) argues, on the other hand,- - using the analogy of a man searching for meaning in lifethat "he felt pity for those who take fright at the span of a century or whose love is bounded by the frontiers of a nation". Thus, humanistic ethics must deal with Otherness and openness ${ }^{2}$.

However, once we enter into the realm of humanness, or what it means to be human, in order to define what it is to be humanistic, the complexity and possibilities are enormous. Here I take an alternative route. Instead of studying the nature of beings, the focus is on the relationalsocial-lived experience of humans. The importance is to highlight that the human purpose is to know the Other. Instead of asking about the human being or human nature, the question that anchors this page is: Who is the Other? Humanistic ethics resides there, in the Otherness or Alterian arena. However, this maneuver won't be humane if the relation with the Other does not deconstruct current views like elitism, authoritarianism, bureaucracy, male-chauvinism, ideologies, and classism, among others. All of them, as it is described below, are outcomes of two pillars of western thought: logical reasoning and control. As Horkheimer and argue, the Enlightenment "is understanding guided by reason".

The importance is to highlight that the human purpose is to know the Other. Instead of asking about the human being or human nature, the question that anchors this page is: Who is the Other? Humanistic ethics resides there, in the Otherness or Alterian arena.

Accordingly, Ritzer argues that "the Enlightenment was characterized by the belief that people could comprehend and control the universe by means of reason and empirical research". Quantum mechanics, as an analogy, serves the purpose of debunking these pillars. Ironically, it was Physics that helped to construct the Newtonian ancient-and current-vision of the world, and today it is Quantum MechanicsSubatomic Physics - that it is helping to deconstruct that monolinear Lebenswelt, which was built using logical reasoning and ideological power-control ${ }^{4}$. The ideas of Immanuel Wallerstein about reason and Modernity perfectly describe the reductionism of this age:

In this situation, in purely intellectual terms, it means we have to rethink our conceptual apparatus, to get rid of the nineteenth century's ideological patina. We will have to be radically agnostic in our empirical and theoretical work, 
while trying to create new heuristic frameworks which will speak about the absence, not the presence, of substantive rationality. (p. 126)

It is important to highlight here that in all the companies I have researched, in which there are humanistic practices, the general managers-CEOs, owners-have transcended the rational-linear, traditional, western mindseti.e. Semco in Brazil, and Acción Fiduciaria \& Area Loft in Colombia. That is why this chapter makes emphasis on this.

At the end of the 20th Century, Margaret Wheatley wrote a book that was regarded as one of the best management books of the year, by the Industry Week (Tom Brown). She reflects on Why do so many organizations feel dead? She found the answers by blending management with Quantum Mechanics, selforganizing systems, and chaos theory. Wheatley argues that the Newtonian model of the world is characterized by materialism and reductionism ${ }^{6}$. This reductionism is an outcome of having logical-reason as the principal foundation of modernity, in which "we manage by separating things into parts; we believe that influence occurs as a direct result of force exerted from one person to another; we engage in complex planning for a world that we keep expecting to be predictable; and we search for better methods for objectively perceiving the world ${ }^{6 \%}$.

The Newtonian model of the world is characterized by materialism and reductionism. This reductionism is an outcome of having logical-reason as the principal foundation of modernity, in which "we manage by separating things into parts.

When someone talks about something being objective, it means it is a result of an observer not touching what he sees. That can only be done in abstraction, ergo by logical-reasoning. The problem is that by being objective, one also chooses to be "scientific". But how can one be scientific in a social activity like management, which is complex and not predict- table? However, we are forced to do this since "we're afraid that we might lose our credibility without our links to Math and Physics" without our links to logical-reason.

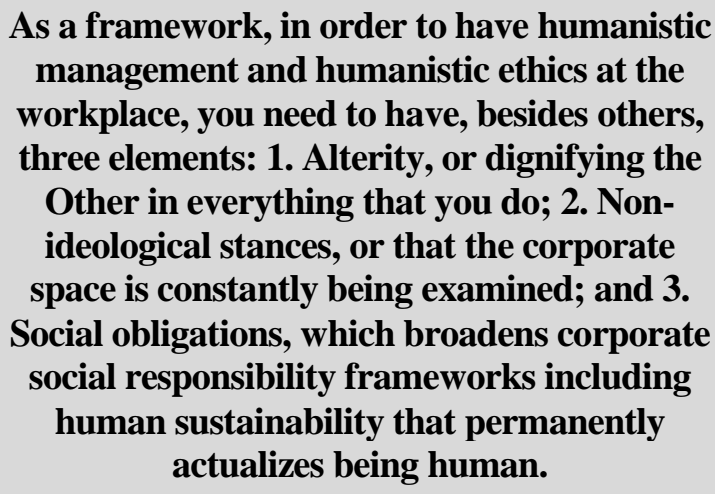

As a framework, in order to have humanistic management and humanistic ethics at the workplace, you need to have, besides others, three elements: 1. Alterity, or dignifying the Other in everything that you do; 2. Nonideological stances, or that the corporate space is constantly being examined; and 3. Social obligations, which broadens corporate social responsibility frame-works including human sustainability that permanently actualizes being human. This approach towards humanistic ethics is a sound reality. It is something that can be achieved. If history is reviewed, several examples can be found ${ }^{\mathrm{i}}$ in which some of these elements have been achieved. The importance is that the manager-being a corporate, governmental, or social-community manager - that wants to work towards a more humanistic and sustainable workplace, should be aware of these three axis or strategic goals. Besides, these are not indicators that show where you are. This approach is a non-linear one, so the stance has to be more of good faith and advancement. The reader of this research project should take the advice of $\mathrm{Zukav}^{8}$ when he states that "the next time you are awed by something, let the feeling flow freely through you and do not try to "understand" it. You will find that you do understand, but in a way that you will not be able to put it into words; you are perceiving intuitively through your right hemisphere." 


\section{ALTERITY, OTHERNESS AND HUMANISTIC ETHICS}

Who is the Other? That is the question.

The Other is also identified as the constitute Other, which refers to what a person considers to be entirely unrelated to their own concept of their self-identity. In words of the Nobel laureate and co-discoverer of Quantum Mechanics, Werner Heisenberg ${ }^{9}$

\begin{abstract}
One could speak of the position and of the velocity of an electron as in Newtonian mechanics, and one could observe and measure these quantities. But one could not fix both quantities simultaneously with an arbitrary high accuracy. ... They are usually called relations of uncertainty or principle of indeterminacy. ... The other way of approach was Bohr's concept of complementarity. ... Bohr considered the two pictures - particle picture and wave picture-as two complementary descripttions of the same reality. ... If one takes into account those limitations which can be expressed by the uncertainty relations, the contradictions disappear.
\end{abstract}

The coidentity-emergence and horizons are akin to what Jung calls inflation, in which there is an "extension of consciousness" that produces an enlargement of the personality leading to the state of inflation having impersonal characteristics of humanity. In a sense, alterity leads toward humanity, the sense of belonging to the whole, or what is called by Christians as brotherhood. Jung saw this inflation or emergence in the I and Thou interaction to "be a kind of supraindividual psychical activity, a collective unconsciousness, as I have called it, distinct from a superficial, relative, or personal unconsciousness" ${ }^{2}$. Some postmodernists, like Schultz, have called this intersubjectivity.

Abraham Maslow in his Towards a Psychology of Being shows an important idea:

To see people primarily as need-gratifiers or as sources of supply is an abstract act. They are seen not as wholes, as complicated, unique individuals, but rather from the point of view of usefulness. ...A fully disinter-rested, desireless, objective and holistic perception of another human being becomes possible only when nothing is needed from him, only when he is not needed. Idiographic, aesthetic perception of the whole person is far more possible for selfactualizing people (or in moments of selfactualization; and further-more, approval, admiration, and love are based less upon gratitude for usefulness and more upon the objective, intrinsic qualities of the perceived person. He is admired for objectively admirable qualities rather than because he flatters or praises. He is loved because he is love-worthy rather than because he gives out love. This is what will be discussed below as unneeding love.

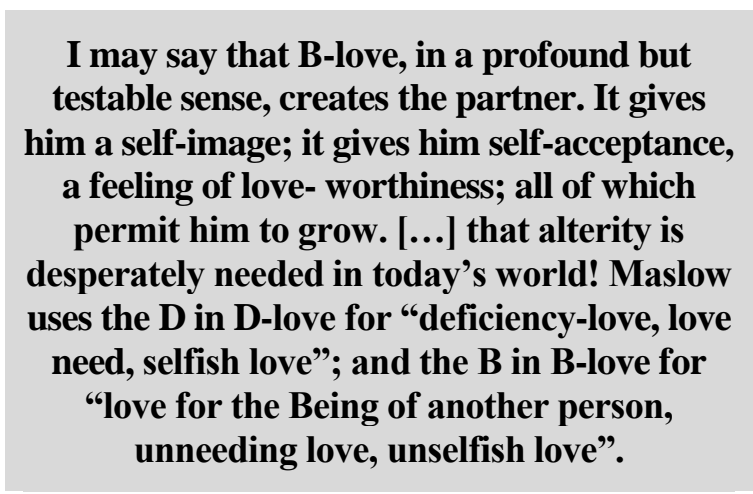

In order to highlight the importance of the unneeding love for the Other, Maslow contrasts Deficiency D-love and Being B-love. Although love is always for the Other as a true other, Maslow summarizes in 10 points the constituencies and experiences of B-love ${ }^{1}$. He argues that B-lovers are "more eager to help the other toward self-actualization, more proud of his triumphs, more altruistic, generous and fostering. The truest, most penetrating perception of the other is made possible by B-love. It is as much a cognitive as an emotionalconative reaction. Finally, I may say that B-love, in a profound but testable sense, creates the partner. It gives him a self-image; it gives him self-acceptance, a feeling of love- worthiness; all of which permit him to grow. It is a real question whether the full development of the human being is possible without it". For me, his key point is that alterity is desperately needed in today's world! Maslow uses the D in D-love for "deficiency-love, love need, selfish love"; and the $\mathrm{B}$ in B-love for "love for the Being of another person, unneeding love, unselfish love". 
This notion of relativism is really important for the humanistic project since acknowledging the existence of another human being signifies dignifying her existence by allocating her diversity as unique, but comprehensible - within her horizon. Instead of talking about a 'normalized' identity, we talked about a unique diversity. It is not a solipsistic diversity that at the end becomes highly individualized, rather an intermingled diversity that considers and respects the horizon of the Other. Thus, the Other exists relative to me, in a social interaction. At the end, my horizon cannot exist independent of the horizon of the Other, but in relation to that horizon. My acts, ethically speaking, ought to take into account the Other.

These ideas are in agreement with Relational Quantum Mechanics which state that nothing exists absolutely, but only relative to interaction with other elements. Everything here is relational; nothing serves itself. There wouldn't be blue if everything were blue. In this form, nature is something complex and highly creative, in which humans co-create reality, as Quantum Mechanics does-and cultural studies and Qualitative Sociology as well-reveals the subatomic world ${ }^{10}$. The key idea of Relational Quantum Mechanics (RQM), in fact, is that the notion of "being" disappears; an entity, in other words, does not exist sui generis in an undisturbed state. Although each phenomenon exists, the specific measurement (identity or quantity) of each one is affected by the other.

For example, Proulx argues that making case studies does not propose one solution, but allows readers to create their own solutions. By doing that, she will start learning the art of management. For example, Walt Shill, who leads Accenture's North American consulting unit, argued: "Strategy, as we know it, is dead". In a similar fashion, Henry Mintzberg wrote a book with the title The Rise and Fall of Strategic Planning where he states that People called planners can sometimes do strange things, just as strategies can sometimes result from strange processes ${ }^{11}$.

Another corporation, 3M, changed the way to make a strategy for very similar reasons. Shaw, Brown \& Bromiley, from 3M highlights, first, the logical-reasoning that blocks countercultural frameworks since virtually all businesspeople plan using lists, outlines and bullets. However, bullet-type strategies "allow us to skip the thinking step", are too generic, and do not clarify the patterns behind a relationship. Thus, at 3M, they changed the traditional, linear thinking approach towards strategy, and introduced a non-linear one: storytelling. They are using strategic stories in order to make explicit the assumptions of one decision, and to delve into the patterned reality in corporations. What is interesting is that they think storytelling helps to discuss assumptions "and help up against senior manager's on mental models ${ }^{12,}$.

This vision is consistent with a Confucianist perspective, and with Maslow's claim that "This [person's] inner nature, as much as we know about it so far, seems not to be intrinsically or primarily or necessarily evil." In this case, stated that A person is both actuality and potentiality. As stated by $\mathrm{Jung}^{2}$, this holistic in-communion human being is individuated, which starts from a personal psyche that "is not a self-contained" but "collective". However, it is not easy to have an individuated self nowadays, since the average person is tied to a competitive social role, or the "mask". The repression caused in the unconsciousness, results from part of the dualism and accompanies socialization linked with Modernity, actually creating a contradiction. The social diversity present in humanity is thus constrained and curtailed, based on the fact that all the virtues and vices of humanity are contained in the collective psyche. However, for traditional scholars, both judgments - the individual and society-cannot be true. Once this repression occurs, coupled with a "personal differentiation" (reduction), reason discovers the irreconciliable nature of the opposites and so individualism is born. Jung clearly argues, with a quantic taste:

We want to be good, and therefore must repress evil; and with that, the paradise of the collective psyche comes to an end. Repression of the collective psyche was absolutely necessary for the development of personality. ... In this way, the outstanding individual is apparently removed from the sphere of the collective psyche, and to the degree that he succeeds in identifying himself with his persona, he is actually removed. (1976: 97) 
The result for society of this human reductionism is a premium on mediocrity, on everything that settles down to vegetate in an easy, irresponsible way, which explains the common apathy of humanity. Accordingly, Jung $^{2}$ argues that Human beings have one faculty which, though it is of the greatest utility for collective purposes, is most pernicious for individualization, and that is the faculty of imitation. Society is organized, indeed, less by law than by the propensity to imitation, implying equally suggestibility, suggestion, and mental contagion".

\section{Self-actualizers are those that can achieve a holistic vision, in which reason and intuition are immanent to perception, giving these people the potentiality of seeing more easily the intrinsic nature of the percept.}

Imitation is one of the illnesses of society, although unrecognizable from the perspective of Modernity. Specifically, most people are committing the sin of "accidie", as Maslow argues, that is failing to do with one's life all that one knows one could do. However, do people shaped by Modernity know what they should do? Do they have capabilities and potentialities? Abraham Maslow, for example, argues that self-actualizers are those that can achieve a holistic vision, in which reason and intuition are immanent to perception, giving these people the potentiality of seeing more easily the intrinsic nature of the percept. Thus, self-actualizers can transcend the logical-rational mindset, and by doing that, they are able to know what their callings are, as Ricardo Semler argues about their workers at Semco. The nonlinear mindset developed by self-actualizers can be seen in the next paragraph when Maslow states that:

[The self-actualizer] can perceive simultaneously the opposites, the dichotomies, the polarities, the contradictions and the incomepatibles. It is as if less developed people lived in an Aristotelian world in which classes and concepts have sharp boundaries and are mutually exclusive and incompatible, e.g. male-female, selfish-unselfish, adult-child, kind-cruel, good-bad. A is A and everything else is not $\mathrm{A}$ in the Aristotelian logic, and never the twain shall meet. But seen by selfactualizing people, it is the fact that A and not $\mathrm{A}$ interpenetrate, and they are one, that any person is simultaneously good and bad, male and female, adult and child, [wave and particle]. One cannot place a whole person on a continuum, only an abstract aspect of a person. Wholeness is non-comparable. (1968:40)

Then Maslow goes on to answer why a similar insight is found in some of his subjects. His answers relate perfectly to what was stated earlier regarding the imitators, social pressure, the diminished personality, and the "mask". Maslow's research shows that self-actualizers were fearless, and certainly less acculturated; that is, they seem to be less afraid of what other people would say or demand or laugh at. They were more self-accepting than the average. Hence, self-actualizers would have less likelihood of changing theirs behaviors once changed to a leader role, as presented in the introduction of this chapter. Based on this finding, another hypothesis can be here, that is, the smaller the "space" between the social self and the intimate self, the more likelihood that humanness will emerge and be actualized, or achieve what Maslow calls "authentic identity".

\section{QUANTUM HUMANISM AND ORGANIZATIONAL LEARNING}

In order to have a learning organization, we need to develop an organizational culture that has five disciplines as its foundation: personal mastery, shared vision, teamwork, mental models, and systemic thinking.
And here we are entering into a very complex and highly relevant topic towards humanistic management. How can we change traditional mental models - organizational learning - that denigrate and dehumanize the human being in corporations, in the economic system, in schools, in families, and so forth? Because 
linear-logical mental models go against higher actualizations of humanness in human beings. It is less likely to have alterity, non-ideological stances and social-obligations inside corporations within the modernitous mental models, present in the majority of CEOs and topmanagers in the world. Remember also that it is highly likely that if they do not have alterity as subordinates, they will not have it as bosses. Among these topics-reductionism vis-à-vis patterns, mental models, linear-logical thinking-Peter Senge, the author of The Fifth Discipline, and an expert on systemic thinking and organizational learning, help us to see a different panorama.

\section{What is needed, is metanoia, an ancient Greek word for "mental displacement or focus change", which is a vital ingredient in order to convert a team into in a great team, and also to convert the personal experience of working into that great team and an unforgettable one.}

In order to have a learning organization, we need to develop an organizational culture that has five disciplines as its foundation: personal mastery, shared vision, teamwork, mental models, and systemic thinking. If Wheatley deals with dead organizations, Senge argues that, on average, corporations don't develop these five disciplines, which explain why our deepest problems are never solved. My argument is that alterity and non-linear thinking are needed in order to develop the five disciplines. That you need a b-love, a collective unconsciousness, a quantum mind, being a self-actualizer, inflation, to allow yourself to block or deconstruct an authoritarian attitude, you won't allow modernitous society to press you to be "normal": a typical boss. What is needed, is metanoia, an ancient Greek word for "mental displacement or focus change", which is a vital ingredient in order to convert a team into in a great team, and also to convert the personal experience of working into that great team and an unforgettable one ${ }^{13}$. This is similar to Maslow's self-actualization, and Semco's organizational culture. It is worth trying that. It explains why Ricardo Semler Semco's CEO, created a school, an atypical school, with the goal of deprogramming adults ${ }^{4}$.
Semco is a Brazilian company that started to apply metanoia 25 years ago. Right now, it is a multinational corporation with more than 5,000 employees, and an ROI of 20-40\% a year in all of its $10+$ business units (Semler, 2004). What is striking is that during the years 2000-2001, when they had 3,000 employees, the number of people leaving the company was two, none being fired! That, for me, is incredibly impressive. But why do people want to work there? Because Ricardo Semler, its CEO, mayor stockowner and enzyme of this process, is highly democratic; he promotes non-linear thinking and has a very humanistic approach towards management that can be summarized as allowing people to do what they want to do. As Semler states, "For a company to excel, employees must be reassured that self-interest, not the company, is their foremost priority [and that] ... success is not measured only in profit and growth".

At Semco, employees do not commit the sin of accidie. They practice alterity when they want to tap the reservoir of talent of their people; they practice non-ideological stances in which all information is available, they practice the whyway; and they embrace several social-obligations since they are zero tolerant for corruption; they protect the environment, and social-sustainability transcends their buildings.

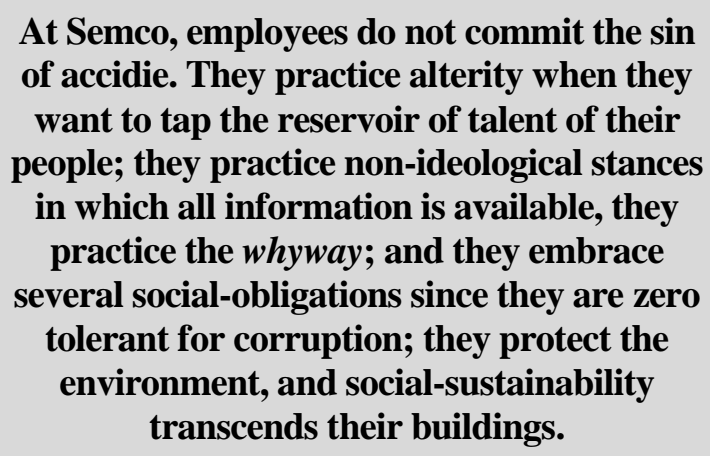

The metanoia that is needed was summarized table 1. It should be clear for the reader that it is more likely that humanistic ethics flourishes from the integrative columns than from the assertive ones. It should be clear, too, that in order to emerge - or actualize - alterian attitudes, non-ideological stances, and socialobligations, the non-traditional columns have to be operated in accordance with the manager's mental models. 
Table 1 :

\begin{tabular}{|l|l|l|l|}
\hline \multicolumn{2}{|c|}{ THINKING/KNOWLEDGE } & \multicolumn{2}{c|}{ VALUES } \\
\hline \multicolumn{1}{|c|}{ Assertive } & Integrative & \multicolumn{1}{c|}{ Assertive } & \multicolumn{1}{c|}{ Integrative } \\
\hline Rational & Intuitive & Expansion & Conservation \\
\hline Analytic & Synthesizer & Competition & Cooperation \\
\hline Reductionistic & Holistic & Quantity & Quality \\
\hline Linear & Non-linear & Domination & Association \\
\hline
\end{tabular}

\section{CONCLUSION}

\section{Who is the "Other" should be the starting point for humanistic ethics and for a sustainable workplace. Later on, in a parallel fashion, the possibility to question everything is vital for a humanistic space.}

Who is the "Other" should be the starting point for humanistic ethics and for a sustainable workplace. Later on, in a parallel fashion, the possibility to question everything is vital for a humanistic space. Finally, a community with interdependent individuals, social or shared obligations has to be put into practice. A better world would be more likely to emerge with this humanistic social-philosophy: Quantum Humanism. Another example is the Mondragon Group, one of the biggest cooperations in the world. It is a Bask (Spain) organization. This is an example of a capitalist, non-for profit corporation. Besides, one of its business units is Irizar which has several humanistic management practices. The case study developed by Ramon Casadesus-Masanell and Jordan Mitchell on "Irizar", Harvard Business School, develop in depth the elements of humanistic management ${ }^{14}$.

As a finishing phrase, Quantum Humanistic Management could be summarized by saying that a corporation is humanistic when the human being is an end in itself, and not a mean. That would mean that a company which produces computers has that activity as an 'excuse' because in the end their social obligation is to produce growth and development of the employees based on a long term vision. As Spitzeck et. al. argues "current economic endeavors are often short-term oriented; we create unsustainable wealth, not sustainable well-being". Not only do we live in a planet that generates unequally distributed wealth, but we have a wealth that is not generating well-being, on average. As has been researched by the World Values Survey, after an X amount of income, much money does not provide happiness or well being. Thus, a social obligation for a corporation is to "produce" humanness by generating well-being in human beings and the planet.

Finally, what the subordinate did without being totally conscious, was being normal. Part of the logical-scientific reasoning is to "normalize" everything, that is, standardization and homogenization. When my identity is tied to the social template accepted as normal, because I do not have the sufficient self-esteem to pursue what I really like, but what is socially accepted; then my diversity vanishes, as Jung and Maslow argue. Even though the subordinate does not like the leadership style of his boss, once he was in that position, his weak self-identity, the social pressure, and his inability to deconstruct his mental model, generated an isomorphism effect. Humanistic ethics and humanistic management need to promote metanoia.

\section{Quantum Humanistic Management could be summarized by saying that a corporation is humanistic when the human being is an end in itself, and not a mean. [...] Thus, a social obligation for a corporation is to "produce" humanness by generating well-being in human beings and the planet.}




\section{BIBLIOGRAPHIE}

${ }^{1}$ Fals-Borda, O. (1968). Subversion y cambio social. $2^{\text {nd }}$ ed. Bogotá: Ediciones Tercer Mundo. Fals-Borda, O. 1979. El problema de cómo investigar la realidad para transformarla por la praxis. Gadamer, H.-G. 1994. Truth and Method. New York : Continuum Publishing. Zea, L. 2000. América Latina en sus ideas. $3^{\mathrm{a}}$ edición. México, D.F.: Siglo XXI Editores.

${ }^{2}$ Capra, F. 2000. La trama de la vida. Una nueva perspectiva de los sistemas vivos. Barcelona: Anagrama. Capra, F. (2001). El tao de la física. Una exploración de los paralelismos entre la física moderna y el misticismo oriental. Málaga: Editorial Sirio. Jung, C. 1976. Portable Jung. Middlesex: Penguin. Laudisa, F. and Roveli, C. 2002. Relational Quantum Mechanics. Stanford Encyclopedia of Philosophy. http://plato.standford.edu/ entries/qm-relational Maslow, A. (1968). Towards a Psychology of Being. Princeton, NJ: Van Nostrand (p. 46 et p. 43). Maslow, A. (1970). Motivation and Personality. NY: Harper and Row. Penrose, R. (1999). The Emperor's New Mind. Oxford: Oxford University Press. Prigogine, I. (1997). The End of Certainty. Glencoe, IL: Free Press. Teilhard De Chardin, Pierre and King, Ursula. (1999). Pierre Teilhard De Chardin: Writings. NY: Orbis Books. Zohar, D. and Marshall, I. (1994). The Quantum Society. New York: William Morrow.

${ }^{3}$ Horkheimer, M. and A., Theodor. (1972). Dialectic of Enlightment. NY: Seabury Press. Ritzer, G. 2000. Modern Sociological Theory. McGraw Hill, $5^{\text {th }}$ Edition.

${ }^{4}$ Hughes, J. and Sharrock, W. (1997). The Philosophy of Social Research. $3^{\text {rd }}$ edition. London: Longman.

Kuhn, T. (1996). The Structure of Scientific Revolutions. $3^{\text {rd }}$ edition. Chicago: University Of Chicago Press. Semler, R. (2004). The Seven Day Weekend. Portfolio.

${ }^{5}$ Wallerstein, I. (2000). The Essential Wallerstein. New York : W.W. Norton.

${ }^{6}$ Wheatley, M. (1992). Leadership and the New Science. Learning about Organizations from an Orderly Universe. NY: Berrett-Koehler Publishers, p. 6.

${ }^{7}$ Largacha-Martínez, C. (2006). Theorem f. A Holistic-Humanistic Model of Development. Dissertation. University of Miami. Coral Gables.

${ }^{8}$ Zukav, G. (1979). The Dancing Wu Li Masters. An Overview of the New Physics. London: Bantham (p. 40).

${ }^{9}$ Heisenberg, W. (1999). Physics and Philosophy. The Revolution in Modern Science. NY: Prometheus Books, 42-43.

${ }^{10}$ Lupasco, S. (1968). Nuevos aspectos del arte y de la ciencia. Madrid: Guadarrama, p. 63.

${ }^{11}$ Mintzberg, H. (1994). The Rise and Fall of Strategic Planning. The Free Press, New York.
Proulx, D. (2009). "How to make business cases". Conference at Universidad EAN, Bogotá, Colombia.

${ }^{12}$ Shaw, G., Brown, R., Bromiley, P. (2001). "Strategic Stories: How 3M is Rewriting Business Planning" in Harvard Business Review on Advances in Strategy. HBR paperpack, Boston, 53 et 59.

${ }^{13}$ Senge, P. (2005). La Quinta Disciplina. Granica, Buenos Aires, Argentina.

${ }^{14}$ Ramon Casadesus-Masanell and Jordan Mitchell (2005). "Irizar", Harvard Business School, 9-706-424.

${ }^{15}$ Spitzeck, H., Pirson, M., Amann, W., Khan, S., von Kimakowitz, E. (2009). Humanism in Business. Cambridge University Press. London, p. 6. 


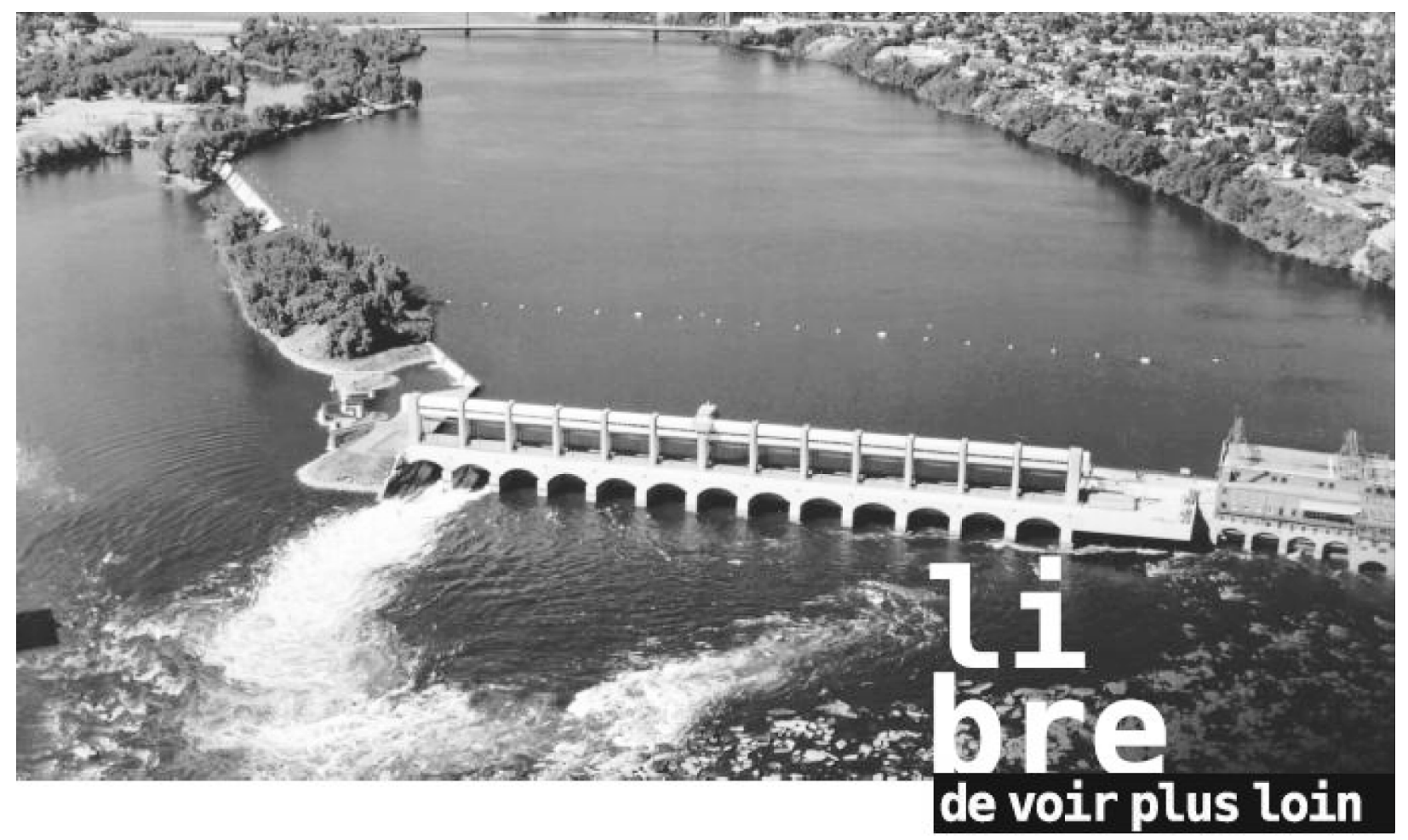

\section{DOCTORAT \\ EN MANAGEMENT DE PROJETS}

- Programme original, unique et novateur

- Possibilités de bourses de prestige et de soutien financier

Pour information :

Université du Québec à Chicoutimi $418545-5011$, poste 5282

uqac.ca/dmp 